\title{
The Archaeology of Old Age
}

\author{
Stig Welinder
}

\begin{abstract}
Prehistoric people sometimes died at an old age to judge by the longevity of life estimated from skeletal data. Anthropology, however, suggests that old age is a much more complex concept than that. The process of growing old that is stressed in the anthropological theory of old people may advantageously be discussed on the basis of prehistoric burial-ground data. Examples from Swedish burial-grounds hint at a cultural variation in the way in which prehistoric societies viewed old age.
\end{abstract}

Stig Welinder: Department of Humanities, Mid Sweden University, SE83125 Östersund, Sweden.

Key words: Age, archaeology, elder, gender, Sweden.

The first verses of the twelfth chapter of Ecclesiastes, compiled around $200 \mathrm{BC}$, describe in poetic metaphors the deterioration of the body, senses, and lust of man. It is a matter of vanity and wisdom, of losing the joy of life, of accepting old age and death, according to the guidance of the shepherd (Norberg 1997). The same process of change affects the skeletons of women and men and makes it possible to study old age within prehistoric archaeology. It is, however, not self-evident that all, or any, prehistoric societies had the same view of the aging process as that of the mythical preacher in the Old Testament. The bodily changes may be looked upon as decline caused by age, as sickness (Sanaker 1984), or in coutless other ways.

\section{AGE AND GENDER}

The present article hints at some ideas concerning old age and how to explore them archaeologically. The starting-point is the modern gender theory. Old age is an important part of an individual's life-span, or rather, as will soon become evident as concerns prehistoric times, of the life-spans of only a few individuals. The latter, however, is not an unambiguous statement. Age, like gender, is a concept that is culturally constructed within each society. No doubt time and the number of solar cycles are universal concepts in the view of physics, but the conception of age and the experience of age are not. Old age certainly is a cultural construct. At least, that is the starting-point from the perspective of gender theory.

Modern gender theory stresses the study of life cycles of individuals. Children mature into a gender, and adults perform as women or men, or as members of other gender groups. Gender theory also stresses that the nature of belonging to a gender group changes in the course of an individual's life as concerns work tasks, social roles, status, and prestige (Sofaer Derevenski 1997b). Thus gender and age are a process, an interlinked process of being inside a gender system, the characteristics of which are 
age-dependent. Throughout its life cycle the gender of an individual will have to be positioned within the gender system of the society in continuous negotiation with other individuals, and the outcome of those negotiations will change.

From an archaeological point of view, it is of importance that material culture is part of the life-long gender-moulding process. This has so far been noted most effectively in studies of burial ritual (Dommasnes 1982 is the Scandinavian classic in the field).

The study of gender today is well established within archaeology (Arwill-Nordbladh 1998 is the latest Swedish contribution). This is not the case as concerns age. The study of children and childhood is gaining ground (Lillehammer 1989 presented the basic theory; Sofaer Derevenski 1994 was an early summary; analyses of actual data are found in Johnsen \& Welinder 1995, Welinder 1998; the discussion goes on in Moore \& Scott 1997). Specific studies of old age, on the other hand, are non-existent ${ }^{1}$, as are, more or less, studies of the variable role of material culture in the full life cycle (Sofaer Derevenski 1997a is an example that explicitly emphasises age as part of the process of engendering; Sellevold et al. 1984 is a pioneering overview of Danish data).

\section{THE CONCEPT OF AGE}

The age of a living person today may simply be counted as the number of solar cycles that the person has experienced. That is chronological age. The age at death of an archaeological individual may be estimated from the biological changes in the skeleton. Thus, the prehistoric individuals do not actually have a chronological age but a biological age, or rather an osteological age, when it is based on an analysis of the skeleton (for methods and the accuracy of the methods, see Mays 1998; Sigvallius 1994 for cremated bones). The biological changes in the skeleton may, however, occur at a different rate in different individuals, or in different groups of individuals. The osteological age is thus not self-evidently the same as the chronological age. For practical reasons the two concepts will, however, be equated in the following.

Thus old people may be distinguishable, although in a way that obviously contradicts the theoretical proposition of age as a cultural construct, not a chronological universal. Nevertheless, the osteological age is the starting-point available today. It should be the starting-point of discussion, not the starting-point of straightforwardly distinguishing old people from non-old people. In any case, the methods of assessing age in skeletons do not allow a differentiation among individuals older than about 50 years. Some scholars in the field say 60 years, others say 55 years. The difference is possibly of no significance, although it ought to be noted that the age at death of cremated individuals is harder to estimate than that of inhumated ones.

Matters are further complicated by the fact that culturally constructed age, that is the cultural age of an individual, is not necessarily stated as the number of solar cycles, or any other physically measurable unit of time. Many societies, although not all, distinguish between age-stages from birth to death. Thus the cultural age of a person

\footnotetext{
${ }^{\prime}$ There is, however, a rising interest in the subject among Swedish students. Two seminar papers have been of importance for the compilation of my article (Emanuelsson 1997; Ahlin Sundman 1999).
} 
may be denoted not as a time-span but as the belonging to a formal age-state, or in some other way denoting the position in the life cycle of the individual.

Cultural age and chronological age may be fairly independent of one another. In societies that distinguish between age-stages, the number of stages may vary, and the boundaries between them certainly are defined in countless ways. Perhaps the simplest way of defining "old age" is to refer to the last one or two stages of such a sequence of age-stages. In societies with generation sets instead of sets of people defined by agestages, the relation between siderial time and age may be quite haphazard. Thus, it is apparent that old age is defined very differently in various societies. Old age may also be independent of the age-stages, or generation sets, and may simply be defined by the bodily and mental deterioration, or certainly by the number of years lived by the individual, that is, by a high chronological age.

It may en passant be noted that old age is unique to humans among the primates. Only humans lend social support to other old humans, thus extending longevity. It is a matter of discussion whether old age is a product of culture or an evolutionary adaptive advantage, or both. Experienced elders, or grandmothers to help with child care, are points in question (Dolhinow 1984).

\section{THE DATABASE}

The starting-point as concerns data is human skeletons, or collections of cremated bones. The number of old people within a population may be estimated from the skeletal data of an entire burial-ground (Siven 1991b).

The idea of burial-ground populations is problematic. There is always the risk of an unknown mixture of individuals with variable susceptibility to disease and death due to, for example, genetic causes, different living-conditions and environmental variation. Wood et al. 1992 has coined the phrase "hidden heterogeneity in risks". In particular, skeletal populations that accumulated during long periods or that derive from only partially excavated sites are problematic. The very idea of paleodemographic reconstructions has been subjected to devastating criticism (Bocquet-Appel \& Masset 1982; cf. Ammerman 1989 and especially the accompanying comment by Sellevold 1989 concerning old individuals).

The data in Table 1 are a haphazard sample of

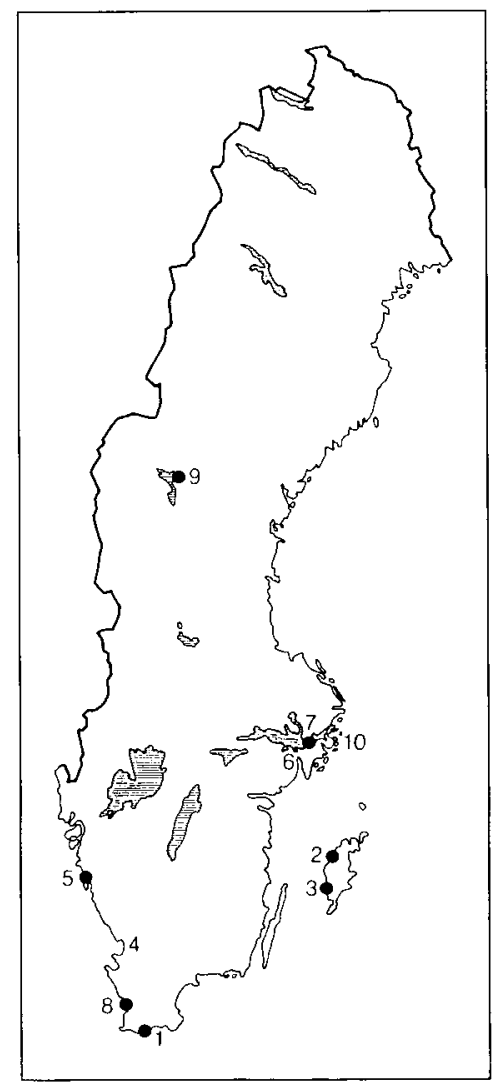

Fig. I. Sweden with provinces and sites mentioned in the text (cf. Tab. I). $1=$ Skateholm; 2 =Visby; $3=$ Ajvide; $4=$ South Halland; $5=$ Ekehögen: $6=$ the Vaiby area; $7=$ the Spainga area; $8=$ Löddeköpinge; $9=$ Västerhus; $10=$ Helgeandsholmen. 


\begin{tabular}{|c|c|c|c|c|c|c|}
\hline Site & Date & $20-40 \mathrm{yrs}$. & $40-60$ yrs. & $>60$ yrs. & Total no. & Reference \\
\hline Skateholm & Mesolithic & 45 & 45 & 10 & 20 & $\begin{array}{l}\text { Persson \& Persson } \\
1984\end{array}$ \\
\hline Visby & $\begin{array}{l}\text { Middle } \\
\text { Neolithic }\end{array}$ & 62 & 33 & 5 & 21 & Janzon 1974 \\
\hline Ajvide & $\begin{array}{l}\text { Middle } \\
\text { Neolithic }\end{array}$ & 32 & 53 & 16 & 19 & $\begin{array}{l}\text { Persson \& Persson } \\
1997\end{array}$ \\
\hline $\begin{array}{l}\text { South } \\
\text { Halland }\end{array}$ & $\begin{array}{l}\text { Late } \\
\text { Bronze Age }\end{array}$ & 50 & 44 & 6 & 36 & Jonsson 1972 \\
\hline Ekehögen & $\begin{array}{l}\text { Pre-Roman } \\
\text { Iron Age }\end{array}$ & 46 & 40 & 14 & 93 & Ekman 1973 \\
\hline $\begin{array}{l}\text { The Vårby } \\
\text { area }\end{array}$ & Iron Age & 50 & 37 & 3 & 147 & Iregren 1972 \\
\hline $\begin{array}{l}\text { The Spånga } \\
\text { area }\end{array}$ & Iron Age & 51 & 46 & 3 & 222 & Sigvallius 1994 \\
\hline $\begin{array}{l}\text { Lödde- } \\
\text { köpinge }\end{array}$ & $\begin{array}{l}\text { Early } \\
\text { Middle Ages }\end{array}$ & 50 & 41 & 9 & 646 & $\begin{array}{l}\text { Persson \& Persson } \\
1983\end{array}$ \\
\hline Västerhus & $\begin{array}{l}\text { Early } \\
\text { Middle Ages }\end{array}$ & 50 & 47 & 4 & 139 & Siven 1991a \\
\hline $\begin{array}{l}\text { Helgeands- } \\
\text { holmen }\end{array}$ & $\begin{array}{l}\text { Late } \\
\text { Middle Ages }\end{array}$ & 31 & 38 & 31 & 428 & Siven 1991a \\
\hline Sweden & 18th century & 30 & 35 & 35 & - & $\begin{array}{l}\text { Johnsen-Welinder \& } \\
\text { Welinder } 1973\end{array}$ \\
\hline $\begin{array}{l}\text { Sweden } \\
(>80 \text { yrs.) }\end{array}$ & 18th century & & $5 \%$ & & & Sigvallius 1994 \\
\hline
\end{tabular}

Tab. 1. The percentage of people older than 60 years among those buried at an age older than 20 years in a selection of Swedish prehistoric and early historical population.

Swedish prehistoric and medieval skeletal populations (Fig. 1). For the sake of comparison the earliest Swedish census data (Hofsten 1986), actually some of the earliest in the world, have been included in the table. The table does not present people of old age in various societies. It simply presents people buried at a chronologically old age, for methodological reasons older than about 60 years. Until fairly recently that proportion was about $5-10 \%$ of all individuals buried at an age older than about 20 years. The change may have occurred during the Middle Ages and not later than during the 18 th century. Today the same percentage is about $75 \%$. Danish data are about the same as concerns prehistoric times (Bennike 1985).

It may be coincidental that also the marriage pattern changed during the Middle Ages (Benedictow 1993). Especially girls married at a higher age towards the end of that period, and accordingly gave birth to their first child at a higher age.

In line with the source-critical remarks stated above, the data in Tables 1-2 should, however, actually not be used for paleodemographic reconstructions like the above suggestion. The proportion of osteologically old people changed in the burial-grounds, not necessarily among the living individuals. The data possibly reflect a change in the attitudes towards culturally old people, not a change in the frequency of osteologically old people. Both aspects are of interest, but it is hard to distinguish between them in prehistoric burial-ground data. 


\begin{tabular}{lcc}
\hline Site & Females & Males \\
\hline Skateholm (> 50 yrs.) & 1 & 6 \\
Visby (>50 yrs.) & 2 & 4 \\
Ajvide (>50 yrs.) & 2 & 8 \\
South Halland ( $>60$ yrs.) & 10 & 1 \\
Ekehögen ( $>60$ yrs.) & 11 & 11 \\
The Vårberg area ( $>40$ yrs.) & 1 & 1 \\
The Spånga area (>50 yrs.) & 36 & 34 \\
The Spånga area ( $>35$ yrs.) & 25 & 26 \\
Löddeköpinge ( $>60$ yrs.) & 3 & 2 \\
Västerhus (> 60 yrs.) & $28 \%$ & $30 \%$ \\
Helgeandsholmen $>50$ yrs.) & $28 \%$ \\
Sweden (>60 yrs.) & $27 \%$ & $33 \%$ \\
\hline
\end{tabular}

Tab. 2. The distribution of females and males among people buried at an old age in the same populations as those of Table I number of individuals or percentage among those buried at an age over 20 years).

\section{THE OSTEOLOGY OF GROWING} OLD

Seemingly very few people lived to become old, that is chronologically old, during prehistoric times. Why did people die? There is not much knowledge, and neither textbooks (Waldron 1994) nor summaries of analyses of early skeletons (Bennike 1985) offer much hope of gaining much knowledge in the near future. Child mortality was high. More men than women died from fighting and violence, and more women than men died from pregnancy and childbirth. Whether many women died for the latter reason, however, is a matter of discussion (Sellevold 1989). If they reached adulthood, most people died in their thirties or forties

from a monotonous diet, inferior houses, and infectious diseases, that is, generally poor living-conditions and health.

In modern Western populations individuals older than 75 years have lost two thirds of their strength as concerns physical working capacity and about half their muscular strength and ability to react. Likewise, they have lost about half their intellectual capacity and what generally may be denoted as intelligence. Also eyesight and hearing are greatly reduced. Old people are dim-sighted and often have cataracts or glaucoma, or still more often macular degeneration. At the age of sixty hearing is normally reduced to a fourth of that of a young person (Man's body 1976; Woman's body 1977).

This process of decline cannot be studied in the prehistoric skeletons. On the other hand, most prehistoric individuals in North Europe seem to have been more or less troubled by bodily wear, joints worn from heavy work, arthritis, and rheumatism already in what is today considered to be middle age. This is especially documented for the Stone Age (e.g. Persson \& Persson 1984; Karlsson 1995).

The changes described above affect the two sexes in roughly the same way, although there also are differences, for example as concerns the calcareous content of the skeleton. Big differences are seen in the reproduction ability. The production of sex hormones starts to decrease at the age of about twenty. Men of about fifty have the same sexual strength as young teenagers. Half of all men are impotent at the age of seventy-five. Women go through the menopause at about fifty. The variation is from about forty to about fifty-five. Factors affecting menopause are among other things standard of living, number of children, age at birth of the last child, body-constitution, and hereditary disposition (Man's body 1976; Woman's body 1977).

The conclusion is simple. Most women during prehistoric times never lived long enough to go through menopause. Table 2 presents the distribution of chronologically 
old people among sexes and periods. The data are buried individuals, which is not necessarily the same as deceased individuals. Considerably more men than women were buried at a high age during the Late Mesolithic and Middle Neolithic. During the Bronze Age and pre-Roman Iron Age the opposite was the case. From around the Birth of Christ there is no significant difference. The data set is small, and it is not confirmed by the Danish data (Bennike 1985). The suggestion, however, is that old age was not dependent solely on biology. To grow old and to be recognised and buried as an elder was a cultural construct with an outcome that was different in various periods and societies. Possibly it was dependent on sex, or rather gender.

The latter comes to mind when considering marriage patterns. To become a widow or a widower, and to remarry, are notable features of growing old. Age at marriage is crucial. What you do in your youth or early middle age becomes of importance in old age (White Riley 1984).

A note of warning must be inserted. The above argument must be seen in the light of The Osteological Paradox (Wood et al. 1992): "Better health makes for worse skeletons" (McGrath 1992). Healthy people survive and accumulate more skeletal lesions before they die at an old age. Unhealthy people die before they have had the chance to accumulate any lesions. Wood et al. 1992 discusses in particular selective mortality. This factor concerns the possibility of being able to study living 20-year-old individuals only as skeletons of dead people. The health of living 20-year-old people is never studied within archaeology. They simply survived until thirty or forty, and will have to be studied among those who were 30 or 40 years old at the time of death.

Selective mortality is of little importance as concerns the data presented in Tables 1-2. All old people died. There is the complete sample of all of them, at least those who were buried in a way that has enabled archaeological excavation and osteological analysis. The latter are the really crucial factors.

\section{THE ANTHOPOLOGY OF OLD AGE}

The view stated in the introduction of this article, that old age is a cultural construct, is merely a special case of the general view of societies held by modern anthropology (Hazan 1994:1):

"Human experience is shaped by human constructs. Through a complex set of social arrangements, cultural codes are deciphered, negotiated and sustained as conceptual devices for interpreting situations, values and norms. [...] By setting up contrasting conceptual categories we bring a sense of order to otherwise unfathomable experience."

The current Western way to deal with the problem that old age causes fear and anxiety, and to keep the problem of the unknown chaos of death under control, is science and occupational skill (Hazan 1994:2):

"The world of the aged is supposedly rendered intelligible by means of widely available information, and through the professional interpretative expertise of welfare workers, doctors, nurses, psychologists, and social policy makers this information 
is transformed into know-how - the measures designed to handle the problems ascribed to the aged and used to plan old-age homes, day centres, welfare facilities and financial benefits on their behalf."

This, however, only functions in the best of worlds. Anthropology may direct attention to unlimited variations in the view of old age, one of which is that being old is a world of its own (Hazan 1994:8):

"[...] the split between the world of the elderly and conceptions about old age remains fundamentally unbridgeable."

If this is true, there is not much future in trying to understand the minds of old people in prehistoric societies on the basis of archaeological data. One way is to start with the simple fact that growing old begins at birth. To be old is to be both old and young. The old ones contains the life and memories of the young (Hazan 1994:8):

"Old age doesn't necessarily mean that one is entirely old - all old, if you follow me. It doesn't mean that for many people, which is why it is so very difficult. It is complicated by the retention of a lot of one's youth in an old body."

These are the words of "The Schoolmaster", at the age of 84 . In line with him, to study old people is to study the accumulation of a life. To study old people in prehistoric societies is partly to study young people. Thus, the question is, whether there is a unique position of being old to focus on.

Fortunately there are other ideas to borrow from anthropology, and there are other ways to tackle old age than to probe the minds of old people. There is the view from outside: How was old age conceptualised? Who was old? What did old people do? What was the status and prestige of old people? What was the relation between old and young people?

In Buraland in North-East Nigeria (Cohen 1984) people in the early 1970s still maintained close links between the living and the dead. The advice, blessings, and wishes of especially the recently deceased generations were sought in shrines tended by the oldest and most senior male members of the society. By interpreting, and manipulating, the will of the dead the male elders became influential in the politics of everyday life.

The elders, females as well as males, are the keepers of the knowledge of kinship. Thus, the sanction of the elders is, or at least was in the 1970s, a prerequisite for a young couple to be married due to the elaborate restrictions on marriage within lineages and clans. This is one of many examples around the world of the power of elders within lineage-based societies. The elders may be honoured and respected as a means of expressing self-identification with the society and its age policy.

Eldership, that is increased leadership, respect, wisdom, experience, and supernatural power due to a proximity to the deceased, is, however, not a universal phenomenon (Cowgill 1972). In Buraland matters were changing during the 1970s (Cohen 1984). The processes of modernisation, migration, and urbanisation, which cause among other things housing shortage and high divorce rates, were leaving old people behind in abandonment and destitution. This applies in particular to women. 
The Old Diviner Woman keeps the jisku, a magical divination metate stone that used to pass from mother to daughter. It was used for diagnosis and divination concerning family matters like sickness and fertility, and especially in the naming of children. The stone tells the Old Diviner Woman the correct name of a newborn. The wrong name will cause poor growth and sickness. Today the villagers are Christians, who baptize their children in church, and when they are ill the children are brought to the well-run mission hospital. The daughter of the Old Diviner Woman, who has waited almost a life-time, has seen the basis of her future power crumple into nothing. Her vision of a decent and dignified old age has turned into frustration, anger, and resignation.

The Lonely Old Farmer speaks for himself (Cohen 1984:342). He had been poisened by an evil, but unknown, neighbour:

"At first I could not bend down to urinate and defecate. After some treatment in the mission hospital it got better. But it is still there and I cannot farm anymore. My wives farm and so we get some food. And my children, all of whom have moved away from the village, send me some money regularly.

But I am very sad. My children are either working elsewhere or in school away from here. It never seems to end; they go from one school on to another one, and when they finally finish they get jobs and work in other places.

I am lonely and old. I want my children and grandchildren around me. This always makes me sad. But I do a lot of weaving and ropemaking."

We are not told the thoughts of his wives. It is their children, too, and the younger of the wives have widowhood awaiting them.

These are modern examples from the 1970s in rural Nigeria. They illustrate that old age is related to time and change. The view of age and ageing is dependent on the concept of time in the individual societies (Östör 1984). To simplify, a society with a linear time-concept, like our own, stresses mobility, change, and progress. In such a society old people are at a basic disadvantage. They are left behind. They are inevitably the losers, although the losing may be a matter of losing well or badly. The former may be the case in societies that stress the cumulative aspects of the linear process of life. In societies with a cyclical time-concept, age may be of little importance.

Among the Buddhists of Bali, growth and decay proceed at different rates for all plants, rocks, animals, and all other things, including humans. All things have their own life cycle. Age is of no importance. Most Balinese do not know their own age. It is simply irrelevant. Death is not an end but a movement to another world, from the Middle World to the Balinese Heaven. The infants and the elders are those closest to the unseen worlds. Every individual moves through many life cycles, from newborn to elder, from elder to ancestor spirit, and back to newborn (Myerhoff 1984).

\section{THE PRESTIGE OF GROWING OLD}

There are various relations between old and young people that can be discussed from a cross-cultural point of view as concerns inequality based on age (Foner 1984).

Anthropological theories of inequality in complex societies have mainly dealt with 
concepts like class, caste, and race (Foner 1984). Whether societies, where differences between individuals are based on sex and age, are to be denoted as egalitarian or not is a matter of discussion. Inequalities based on sex, or rather gender, have been much in focus in recent research. Age is less discussed, although the concept of age stratification was coined some decades ago. It pinpoints the phenomenon that groups have different access to wealth and that some groups possess more power and prestige than other groups due to their belonging to different age-stages. With regard to old age, the advantages of old men compared with the disadvantages of young men have been most to the fore, but things are more complex than that.

In a large number of societies old people enjoy considerable influence, prestige, and wealth. Most commonly, old men exercise control over young men and women. Especially the relation between old and young men may be one of strain and conflict (cf. Hodder 1982). This is less common as concerns old men and young women. In the day-to-day activities the young women of the household most often are governed by older women. Thus, conflict between old women and young women is more frequent than conflict between old men and young women. Old men may, however, select the spouses of the young women, and not always according to the wishes of the latter.

So the common ranks of subordination are old men - old women - young women and old men - young men - young women. This makes the relation old women young men a problematic one. The young men have an advantage due to their sex, but the old women have one due to their age. In addition, the mother-in-law is the giver of the wife. The contradictory situation may be solved by the establishing of taboos that guide the two potential combatants to avoid one another.

It is, however, not a universal rule that the old people are situated above the young people. Obviously, when incapacitated, the old people have to depend on the young for support and care as they increasingly cannot manage the daily affairs of neither their own nor others. They may, however, be social losers already before becoming bodily and mentally debilitated. Social loss may be built into the move from one stage to another in age-set societies. Especially in peasant societies, the elders may transfer all or much of their resources and power to their children, that is to the young ones, at marriage.

It is notable that incapacitated, old men are more often looked upon as useless than old incapacitated, old women. The former have lost the strength necessary for the male tasks, while the latter may be useful for tasks like cooking and child-care. Even a very old mother-in-law may be of valuable help to "a revengeful daughter-in-law" in "washing vegetables for dinner and rocking babies to sleep" (Foner 1984:116). Old people without sons or daughters of their own or close kin nearby, which may be the case for widows in patrilocal societies, are in a precarious situation.

\section{THE ARCHAEOLOGICAL STARTING-POINT}

Growing old inevitably comes to an end at death. In prehistoric societies most people died before becoming chronologically old in the modern sense of the concept. Death is one of the areas of uncertainty, anxiety, impotence, and disorder where ritual is used 
to create understandable order out of the threatening chaos. Ritual also organises the life of the living. The move from one stage to another in the lifecycle, or along the ladder of an age-set society, is marked by ritual. Thus, age and ritual are closely interlinked (cf. van Gennep 1960; Myerhoff 1984). The ultimate ritual at the ultimate point of life, be it the end or the beginning, is the burial-ritual performed at death.

For the time being, the burial-ritual provides the optimal opportunity for prehistoric archaeology to study the process of growing old and the position of the elders within a prehistoric society. It can be assumed that the objects associated with the deceased have something of importance to tell about the deceased in relation to other members of the same society buried in the same burial-ground. The strategy is the same that was used within gender archaeology in the 1980s and within the archaeology of children in the 1990s (Johnsen \& Welinder 1995).

\section{THE ARCHAEOLOGICAL CONCEPT OF OLD AGE}

Before discussing a selection of burial-grounds, it should be stated again that old age in burial-ground populations is the osteological approximation of chronological age. Individuals older than 50-60 years may be regarded as being of old age. The analysis and discussion of the data will focus on cultural age, that is the problem of whether or not the osteologically oldest individuals were buried according to rituals of their own, thus indicating that old people held a position of their own in the society in question. It must, however, be remembered that this is a poor approximation of cultural age.

\section{MIDDLE NEOLITHIC}

The Ajvide burial-ground on the Baltic island of Gotland dating from the Middle Neolithic, contains 24 individually buried skeletons with reasonably accurate sex and age classifications (Burenhult 1997a, b). Most of the skeletons are associated with sets of objects, with one or several of 23 types (Vedin 1997). Thus, a presentation of the data set as a PCA plot derived from a $24 \times 23$ matrix is called for (Blankholm \& Price 1991).

The axes of the plot may be given more or less tentative interpretations, from which a complex interpretation of the scatter of units, that is the buried individuals, may be suggested. The first axis stresses the presence, and absence, of swine tusks, seal teeth, and adzes and axes. These presumably prestigious objects are opposed to small bone objects and beads. The second axis stresses on the one hand pottery, fish-bones, and seal-bones, and on the other hand chisels, retouched flintflakes, hammer-stones, and arrow-heads. The axis seems to put food in opposition to handicraft. However, none of the axes distinguishes unequivocally between women and men, or between young and old individuals (Fig. 2).

Both axes together classify most women and men into two groups. Both some women and some men are associated with the prestige objects, while the food handicraft opposition generally is also a women - men opposition.

Three out of five children are grouped together with the men. The oldest child, 10 years old, is grouped together with the women. The next oldest child, 9 years old, is 
grouped in between the two gender groups. These individuals do not fit perfectly into the pattern of the age-set society previously reconstructed from other Gotlandic Middle Neolithic graves (Andersson et al. 1995). They are buried with working-tools, such as axes, already from the age of about 8 years, while the previously analysed set of graves suggested the introduction of regularly occurring tool kits at about the age of 12 years.

Some men buried at a chronologically old age, that is more than 50 years, are characterised by prestige objects. The same is valid for one young woman. The prestige objects are generally more common among young women than young men. So the two age groups associated with prestige objects are some old men and most young women.

There is only one old woman among the analysed individuals. She was buried

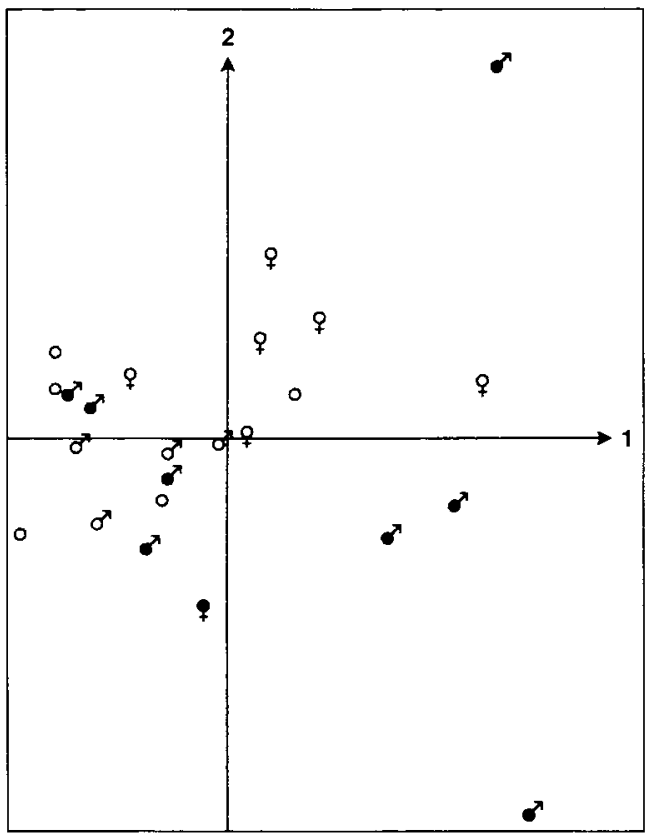

Fig. 2. PCA plot of the individuals in the Middle Neolithic Ajvide burial-ground: women, men, and children (circles). Individuals older than 50 years are denoted with black. together with a tool-kit, which is otherwise mostly found in men's graves. This is an indication of a change in position within the gender-system of the society by a woman after her menopause. An ethnographically well-known 92-year-old female hunter in Kamtjatka is a parallel that comes to mind (Willemark 1997).

Within the Ajvide burial-ground, which is not necessarily the same as the living society, the elders were men, some of which were honourably buried. Few women grew old enough to go through menopause. If they did, they could change their gender position. Men, if they could, did not.

\section{LATE BRONZE AGE}

The number of objects in the Late Bronze Age cremation graves in South Halland is presented as mean values (Tab. 3). Thus, the variation among individuals cannot be studied.

Young women were not buried, young men were. Women were buried together with the highest number of objects in reproductive age. After menopause, the number of objects declined. For men it was the opposite. The number of objects increased. The older the man, the more objects were deposited together with his cremated bones. However, very old men were not buried at all. In accordance with the lack of young women's graves, this may be due to a statistical error resulting from the low total 
number of graves (cf. Tab. 1).

Among the elders of the Late Bronze Age graves in South Halland there were more women than men, but the men were given 2-3 times more objects when buried. This notably ranked chiefdom society (Larsson 1986) honoured women in reproductive age and men in old age, but everywhere men were honoured more than women.

\section{IRON AGE}

No. 156 Spånga is a big Iron Age cremation burial-ground in the vicinity of Stockholm. It is of interest mainly from a source-critical point of view.

Among the Early Iron Age individuals in the burial-ground very few old people have been identified, that is individuals older than 50 years (Tab. 4). The same is valid for children. In addition very few individuals have been sexed. The reason is that during the Early Iron Age the bones were taken from the cremation pyre and moved for deposit in the grave. In the process they were cleansed and crushed, and only part of them, sometimes a tiny part, was included in the grave. Too much information necessary for the osteological analysis to be successful was lost. Thus, little is known about elders. They were, like the children, equipped with few objects in the same way as most members of their society (Tab. 6).

During the Late Iron Age, including the Viking Age, the bones were moved more or less in their totality together with charcoal and soot from the pyre to the grave. Sex and age analysis is therefore more profitable (Tab. 5). Proportionally more men than women older than 35 years were buried. No individuals older than 50 years were buried, or rather detected during the process of osteological age-definition. That was that, as concerns old people. It should be added, of course, that about half the women had gone through menopause at the time of their burial.

\begin{tabular}{lccc}
\hline Age interval (yrs.) & Females & Males & Indet. \\
\hline $0-14$ & & & 0.2 \\
$14-20$ & & 1.0 & \\
$20-40$ & 1.2 & 1.5 & \\
$40-60$ & 0.8 & 1.8 & \\
$>60$ & 0.5 & & \\
\hline
\end{tabular}

Tab. 3. The number of objects per individual in Late Bronze Age graves in South Halland (modified from Wiberg 1995).

\begin{tabular}{lccc}
\hline Age interval (yrs.) & Females & Males & Indet. \\
\hline $0-7$ & & & 1 \\
$0-14$ & & & 1 \\
$18-44$ & 1 & & 3 \\
$35-64$ & & 1 & 3 \\
$18-89$ & & & 24 \\
$50-89$ & & 1 & 2 \\
indet. & & & 15 \\
\hline
\end{tabular}

Tab. 4. Age and sex distribution among the cremated individuals from the Early Iron Age in the burial-ground No. 156, Spanga (no. of individuals; data from Sigvallius 1994).

\begin{tabular}{lccc}
\hline Age interval (yrs.) & Females & Males & Indet. \\
\hline $0-7$ & & & 3 \\
$10-24$ & & 2 & \\
$18-44$ & 6 & 5 & \\
$35-64$ & 7 & 8 & 4 \\
$18-89$ & 10 & 2 & 6 \\
indet. & & & 3 \\
\hline
\end{tabular}

Tab. 5. Age and sex distribution among the cremated individuals from the Late Iron Age in the burial-ground No. 156, Spanga (no. of individuals; data from Sigvallius 1994). 


\section{CONCLUDING NOTE}

The anthropological experience suggests that old age may be studied as the process of growing old. That is exactly what is possible from archaeological prehistoric burial-ground data. It is not known who, if anyone, among the individuals in the burialgrounds was considered old as concerns cultural age, and why, by the members of the living society. Someone, however, is always the osteologically, that is approximately the chronologically, oldest person. The individuals can be lined up from the youngest to the oldest, and their associated objects or other features of the burial-ritual of their society can be seriated along the line. That is the archae-

\begin{tabular}{lccc}
\hline AOT & Total no. & $<15$ yrs. & $>50$ yrs. \\
\hline 0 & 10 & & \\
1 & 16 & & 2 \\
2 & 16 & 1 & \\
3 & 7 & 1 & 1 \\
4 & 1 & & \\
5 & 1 & & \\
6 & & & \\
7 & & & \\
8 & 1 & & \\
\hline
\end{tabular}

Tab. 6. Number of object types (AOT) per. individual in Early lron Age graves at the burial-ground No. 156. Spainga, distributed according to age (data from Biuw 1992). ological presentation of the process of growing old.

To be old is, however, not necessarily the same as having approached the end of a long life-span. To be old is to be considered old by others, and possibly to experience elderhood in the eyes of oneself. That is cultural age, which the anthropological experience suggests to be a concept of complexity and variation. In the same way as gender is much more difficult to grasp than sex, cultural age is much harder to grasp than chronological, that is osteological, age in skeletal populations.

The three sets of burial-ground data discussed are not meant to form an evolutionary view of elderhood from the Stone Age to the Iron Age. On the contrary, they show that prehistory, like the anthropological experience, contains complexity and variation that has to be disentangled from contextual studies, with full consideration for source criticism. However, one conclusion seems to be indicated.

All prehistoric individuals have had a childhood; all, or at least most, individuals have had a gender, one or possibly several different ones, one after the other, but all prehistoric individuals did not grow old. Few grew chronologically older than 40-50 years, very few older than 50-60 years. People did not anticipate growing old, although it is hard to guess if they desired it. In prehistoric societies there were few elders. In modern Western societies almost everybody grows old, and the proportion of old people is high and still increasing. Thus, prehistoric life was different from modern life, and prehistoric societies were different from modern societies.

Analysing and discussing the archaeology of old age adds a dimension to the study of humankind, and to the human experience. It is still an open question whether this will add to the anthropological experience, or merely duplicate it.

Enlish revised by Laura Wrang. 


\section{REFERENCES}

Ahlin Sundman, E. 1999. Gammal på vikingatiden. Seminar paper. Institutionen för arkeologi, Stockholms universitet, Stockholm.

Ammerman, A.J. 1989. Population studies and the archaeologist. Norwegian Archaeological Review 22:2. Pp. 65-76, 86-87.

Andersson, G., Welinder, S. \& Westeson, $\AA$. 1995. Barndomens gränser under mellanneolitikum. In: Johnsen, B. \& Welinder, S. (Eds). Arkeologi om barn. Occasional Papers in Archaeology 10. Pp. 2941.

Arwill-Nordbladh, E. 1998. Genuskonstruktioner i nordisk vikingatid. Förr och nu. GOTARC. Gothenburg Archaeological Theses B 9.

Benedictow, O.J. 1993. The Medieval Demographic System of the Nordic Countries. Oslo.

Bennike, P. 1985. Palaeopathology of Danish Skeletons. A Comparative Study of Demography, Disease and Injury. Copenhagen.

Biuw, A. 1992. Norra Spånga. Bebyggelse och samhälle under järmåldern. Stockholm.

Blankholm, H.P. \& Price, T.D. 1991. Arcospace. A Package for Spatial Analysis of Archaeological Data. Ver. 3.0. Duplicate.

Bocquet-Apple, J.-P. \& Masset, C. 1982. Farewell to paleodemography. Journal of Human Evolution 11. Pp. 321-333.

Burenhult, G. 1997a. Gravarnas vittnesbörd. In: Burenhult, G. (Ed). Ajvide och den moderna arkeologin. Pp. 52-70. Stockholm.

Burenhult, G. 1997b. Introduction. In: Burenhult, G. (Ed). Remote sensing, Vol. I. Applied techniques for the study of cultural resources and the localization, identification and documentation of sub-surface prehistoric remains in Swedish archaeology. Theses and papers in North-European archaeology 13:a. Pp. IX-XXI.

Cohen, R. 1984. Age and culture as theory. In: Kertzer, D.I. \& Keith, J. (Eds). Age and anthropological theory: New York.

Cowgill, D.O. 1972. A theory of aging in cross-cultural perspective. In: Cowgill, D.O. \& Holmes, L.D. (Eds). Aging and modernization. Pp. 1-13. New York.

Dolhinow, Ph. 1984. The primates: age, behaviour, and evolution. In: Kertzer, D.I. \& Keith, J. (Eds). Age and anthropological theory. Pp. 65-81. New York.

Dommasnes, L.H. 1982. Late Iron Age in Western Norway. Female roles and ranks as deduced from an analysis of burial customs. Norwegian Archaeological Review 15:1-2. Pp. 70-84.

Ekman, J. 1973. Exkurs 5. Benbestämningar, Ekehögen. In: Cullberg, Kj., Ekehögen - Backa Röd Valtersberg. Frägor om kronologi och kulturkontakter under yngre föromersk järnålder i Göteborgsområdet. Studier i nordisk arkeologi 12. Pp. 227-242.

Emanuelsson, M. 1997. Forntidens åldringar-en introduktion. Seminar paper. Institutionen för arkeologi, Umeå universitet, Umeå.

Foner, N. 1984. Ages in conflict. A cross-cultural perspective on inequality between old and young. New York.

Hazan, H. 1994. Old age: constructions and deconstructions. Cambridge.

Hodder, I. 1982. Symbols in action. Ethnoarchaeological studies of material culture. Cambridge.

Hofsten, E. 1986. Svensk befolkningshistoria. Några grunddrag i utvecklingen frän 1750. Stockholm.

Iregren, E. 1972. Värby och Värberg. II. Studie av kremerat människo- och djurbensmaterial frän järnaldern. Theses and papers in North-European archaeology 1.

Janzon, G.O. 1974. Gotlands mellanneolitiska gravar: Acta universitatis stockholmiensis. Studies in NorthEuropean Archaeology 6.

Johnsen, B. \& Welinder, S. (Eds). 1995. Arkeologi om barn. Occasional Papers in Archaeology 10.

Johnsen-Welinder, B. \& Welinder, S. 1973. Järnaildersgravfält i Mälardalen. Acta archaeologica Lundensia. Ser. in $8^{\circ}$ minore 2 . 
Jonsson, R. 1972. Osteologisk analys av brandgravsmaterial från bronsåldershögar och bronsåldersgravar i södra Halland. In: Lundborg, L. Undersökningar av bronsåldershögar och bronsåldersgravar $i$ södra Halland. Hallands museum 2. Pp. 131-142.

Karlsson, E. 1995. Handikapp och status under mellanneolitikum på Gotland. Seminar paper. Institutionen för socialt arbete, Mitthögskolan, Östersund.

Larsson, Th.B. 1986. The Bronze Age metal work in southern Sweden. Aspects of social and spatial organization 1800-500 B.C. Umeå.

Man's body. London 1976.

Mays, S. 1998. The archaeology of human bones. London.

McGrath, J.W. 1992. Comment. Current Anthropology 33:4. Pp. 362-363.

Moore, J. \& Scott, E. (Eds). 1997. Invisible people and processes: writing gender and childhood into European archaeology. London.

Myerhoff, B. 1984. Rites and signs of ripening: the intertwining of ritual, time, and growing old. In: Kertzer, D.I. \& Keith, J. (Eds). Age and anthropological theory. Pp. 305-330. New York.

Norberg, B. 1997. Åldrandet inifrån - forntid och nutid. Sydsvenska medicinhistoriska sällskapets årsskrift 1996-97. Pp. 153-155.

Östör, Á. 1984. Chronology, category, and ritual. In: Kertzer, D.I. \& Keith, J. (Eds). Age and anthropological theory. Pp. 281-304. New York.

Persson, E. \& Persson, O. 1997. The osteo-anthropological analysis of skeleton material from Hablingbo and Ajvide, excavation seasons 1983-86, 1992-95. In: Burenhult, G. (Ed). Remote sensing, Vol. I. Applied techniques for the study of cultural resources and the localization, identification and documentation of sub-surface prehistoric remains in Swedish archaeology. Theses and papers in NorthEuropean archaeology 13:a. Pp. 3-14.

Persson, O. \& Persson, E. 1984. Anthropological report on the mesolithic graves from Skateholm. Southern Sweden. I. Excavation seasons 1980-1982. University of Lund, Institute of Archaeology, Report Series 21.

Persson, P.O. \& Persson, E. 1983. The Löddeköpinge investigation V. Report on the anthropometrics of the skeletons from the early medieval cemetery in Löddeköpinge (Scamia. S. Sweden). University of Lund, Institute of Archaeology, Report Series 19.

Sanaker, A.1984. "It's just old age": old age as a diagnosis in American and Chinese medicine. In: Kertzer, D.I. \& Keith, J. (Eds). Age and anthropological theory. Pp. 250-280. New York.

Sellevold, B.J. 1989a. Comments to 'Population Studies and the Archaeologist'. Norwegian Archaeological Review: 22:2. Pp. 77-83, 84-87.

Sellevold, B.J. 1989b. Fødsel og død. Kvinners dødelighet i forbindelse med svangerskap og fødsel i forhistorisk tid og middelalder, belyst ut fra studier av skjelettmaterialer. In: Gunneng, H., Losman, B., Møller Knudsen, B. \& Reinholt, H. (Eds). Kvinnors rosengård. Medeltidskvinnors liv och hälsa, lust och barnafödande. Skriftserie från Centrum för kvinnoforskning vid Stockholms Universitet 1. Pp. 79-96.

Sellevold, B.J., Lund Hanssen, U. \& Balslev Jørgensen, J. 1984. Iron Age man in Denmark (Prehistoric man in Denmark III). Nordiske Fortidsminder B:8. Copenhagen.

Sigvallius, B. 1994. Funeral pyres. Iron Age cremations in North Spanga. Theses and papers in osteology 1.

Siven, C.H. 1991a. On estimating mortalities from osteological age data. International Journal of Anthropology 6:2. Pp. 97-110.

Siven, C.H. $199 \mathrm{lb}$. On reconstructing the (once) living population from osteological age data. International Journal of Anthropology 6:2. Pp. 111-118.

Sofaer Derevenski, J. 1994. Where are the children? Accessing children in the past. Archaeological Review from Cambridge 13:2. Pp. 7-20.

Sofaer Derevenski, J. 1997a. Age and gender at the site Tiszapolgár-Basatanya, Hungary. Antiquity 71. Pp. 875-889. 
Sofaer Derevenski, J. 1997b. Linking age and gender as social variables. Ethnographisch-Archäologische Zeitschrift 38. Pp. 485-493.

van Gennep, A. 1960 (1908). The rites of passage. Chicago.

Vedin, E.-M. 1997. Döden på Ajvide. Begrawningsritualer på ett gropkeramiskt gravfält. Seminar paper. Arkeologiska institutionen, Stockholms universitet, Stockholm.

Waldron, T. 1994. Counting the dead. The epidemiology of skeletal populations. Chichester.

Welinder, S. 1998. The cultural construction of childhood in Scandinavia, 3500 BC - 1350 AD. Current Swedish Archaeology 6. Pp. 185-204.

White Riley, M. 1984. Foreword. In: Kertzer, D.I. \& Keith, J. (Eds). Age and anthropological theory. Pp. 7-10. New York.

Wiberg, E.-L. 1995. Föremål och fyndassociationstyper knutna till kön och ålder. Seminar paper. Institutionen för kultur och humaniora, Mitthögskolan, Östersund.

Willemark, K. 1997. Kvinnor, män och stenhantverk. In: Johnsen, B. \& Welinder, S. (Eds). Gender och arkeologi. Pp. 50-62. Östersund.

Woman's body. London 1977.

Wood, J.W., Milner, G.R., Harpending, H.C. \& Weiss, K.M. 1992. The osteological paradox. Current Anthropology 33:4. Pp. 343-370. 